\title{
The Performance of Wheat Varieties in Resisting the Drought at Nilphamari District of Bangladesh
}

\author{
Matiur Rahman ${ }^{1}$, Meghna Guhathakurta ${ }^{2}$, Musfikur Rahman ${ }^{3}$ \\ ${ }^{1}$ Research Initiatives Bangladesh, Dhaka, Bangladesh \\ ${ }^{2}$ Research Initiatives Bangladesh, University of Dhaka, Dhaka, Bangladesh \\ ${ }^{3}$ Maternal and Child Health Division, International Center for Diarrhea Disease Research, Dhaka, Bangladesh
}

Email address:

rmdmatiur@gmail.com (M. Rahman),meghna.guhathakurta@gmail.com (M. Guhathakurta), jony746@gmail.com (M. Rahman)

\section{To cite this article:}

MatiurRahman, MeghnaGuhathakurta, MusfikurRahman. The Performance of Wheat Varieties in Resisting the Drought at Nilphamari District of Bangladesh. American Journal of BioScience. Vol. 7, No. 2, 2019, pp. 38-44. doi: 10.11648/j.ajbio.20190702.12

Received: October 31, 2018; Accepted: April 15, 2019; Published: June 28, 2019

\begin{abstract}
The present study was undertaken to evaluate the performance of resisting the drought to wheat varieties at three Upazilas of Nilphamari district of Bangladesh namely, Saidpur, Nilphamari Sadar and Jaldhaka. The main objectives that the study aimed to achieve include, (i) identification of drought stress tolerant wheat varieties by the small and marginal farmers through adaptive trials thus found more productive and profitable; and (ii) demonstration of modern wheat cultivation technologies generated awareness, improved knowledge, attitude and perceived adoption of modern wheat production among the demonstrating as well as neighbouring farmers. Four separate trials for identification of drought stress tolerant varieties were planned and implemented using Split-Plot design. Crop production technologies as recommended by BARI were used in the trials. Study findings showed comparatively lower yield in 'zero' irrigation i.e. rainfed condition in all the varieties (ranging from 3.89 tons to 4.05 tons/ha, average being 3.97 tons/ha) as against single irrigation (4.07 tons- 4.61 tons/ha, average being 4.32 tons/ha), two irrigation ( 4.11 tons -4.59 tons/ha, average being 4.41 tons/ha) and three irrigations ( 4.56 tons4.94 tons, average being 4.70 tons/ha). The yield difference between ' 0 ' \& $1,1 \& 2$, and $2 \& 3$ irrigations did not reveal a significant difference in most of the varieties. But in most of the varieties, significant differences were observed between ' 0 ' and 3 irrigations. In ' 0 ' irrigation, all the varieties performed similar with respect to yield, but BARI Gom 21 performed slightly better over the other varieties.
\end{abstract}

Keywords: Drought, Climate Change, Irrigation, Wheat Variety, Adaptive Trail

\section{Introduction}

The area under wheat in Bangladeshh as decreased sharply in recent years due to a change in the dominant rice-based consumption pattern. Bangladesh wheat production was at level of 1.31 million tonnes in 2017, down from 1.35 million tonnes previous year, this is a change of $2.72 \%$ [1]. Nutritionally, wheat is superior to rice and its cultivation has specific advantages over other crops grown in Rabi season such as: (i) low water requirement; (ii) can be grown successfully using residual soil moisture; (iii) less damage from insect pests and diseases; (iv) dependable consumer demand, easy utilization and marketing; (v) low production cost; and (vi) higher market price. There exist a huge potentiality of enhancing wheat production both horizontally and vertically using available high yielding varieties and production technologies.

The global mean temperature has risen by $7^{\circ} \mathrm{C}$ since 1860 . Over the same period, $\mathrm{CO} 2$ concentrations have increased by 46 percent [2] and there have been not able changes in the pattern of temperature, rainfall, drought, flood, and salinity intrusion causing major problems to crop production. Livelihood and food security of people are now under threat owing to the erratic behaviour of climate. If current trend in human population growth and food comsumption continue crop production must be increased by $60 \%$ by mid-century to meet food demand and reduce hunger [3]. but climate change will make this task more difficult [4]. Population growing and consumption is the big challeng for the current world. Continuing population and consumption growth will mean that the global demand for food will increase for at least 
another 40 years. Growing competition for land, water, and energy, in addition to the overexploitation of fisheries, will affect our ability to produce food, as will the urgent requirement to reduce the impact of the food system on the environment [5]. The International Food Policy Research Institute projections indicate that world demand for wheat will rise from 552 million tons in 1993 to 775 million tons by 2020 [6]. At the same time, climate change-induced tem premature increases are likely to reduce wheat production in developing countries (where around $66 \%$ of all wheat is produced) by $20-30 \%$ [7]. The Intergovernmental Panel on Climate Change (IPCC) [8] noted that global climate change will have a major impact on crop production. CIMMYT and ICARDA [9] estimated that 20-30\% wheat yield losses will occur by 2050 in developing countries as a result of a predicted temperature increase of $2-38 \mathrm{C}$. On a global scale, these yield losses will not be fully compensated by yield gains in high-latitude regions (Canada, Russia, Kazakhstan and Northern USA), estimated at 10-15\% [10], since major wheat producers such as France have already reported yield reductions due to increasing temperatures [11]. Due to increasing trend of drought and excessive use of ground water for irrigating Boro season rice during the dry period have made cultivation of rice less lucrative to the farmers in one hand and surfaced a number of environmental hazards. Immediate visible effects are (i) serious depletion of ground water level, and (ii) accumulation of arsenic and other harmful elements in the upper soil level in many parts of the country. The most direct approach has been identifying an appropriate crop maturity that maximizes growth and the accompanying yield component development. Beyond that, the improvement of response to drought has been rare [12]. Farmers are cultivating these varieties as they are getting more yields. Apart from this, many farmers are now become more interested towards wheat farming as they are facing problems in cultivation of boro paddy in the water-stress condition in the Barind area in 25 Upazilas of Rajshahi, Naogaon and Chapainawabgonj districts [13]. Time has now come to consider reduction of irrigation by using underground water and switching to crops that can give productive yield under less or non-irrigated conditions using the residual moisture. Both scientists and farmers have found wheat as an important crop that can give potentially satisfactory yield and profitability under low irrigated/rainfed condition within less than one-half time of longer duration Boro rice varieties. Wheat Research Centre of Bangladesh Agricultural Research Institute (BARI) has developed and released a number of high yielding wheat varieties [14] which are relatively drought and heat stress tolerant including supporting production technologies. Major challenges in a vertical increase of production centered in (i) continuous development of high yielding disease-resistant varieties suited to the needs and agro-climatic environment of the farmers; and (ii) dissemination of existing high yielding varieties and production technologies among the farmers. Prime production problems include:

i Spikelet Sterility due to high-temperature stress at the reproductive stage is a major problem for wheat production in Bangladesh. As most of the wheat sown in late (i.e. middle of December to late December), the crop experience high heat stress at the reproductive stage during March-April causing spikelet sterility and significant yield reduction. WRC of BARI has developed a good number of heat tolerant high yielding varieties. Sowing seed in optimum planting time i.e. from 15 November to 30 November may help in escaping high-temperature stress.

ii Small and marginal farmers mostly cultivate wheat using residual soil moisture. So, varieties which can be grown under the rainfed condition, tolerant to moisture stress i.e. drought-likesituation required to be identified by the farmers themselves.

Wheat varieties released by BARI in recent years are mostly heat stress tolerant thus the risk of spikelet sterility has been encountered largely. But most of the farmers still have little or no access to these recently released heat stress tolerant varieties and supporting technologies. Farmers-led adaptive trial and demonstration can help the farmers to identify their preferred varieties and supporting production technologies against spikelet sterility, drought, and cold stress.

\section{Objectives}

With the goal of assisting the farmers in identifying their own preferred wheat varieties that can provide satisfactory yield and productivity against drought stresses, the present study aimed at achieving the following objectives:

i To demonstrate that drought stress tolerant wheat varieties identified by the small and marginal farmers through adaptive trials are more productive and profitable.

ii Demonstration of modern wheat cultivation technologies generated awareness, improved knowledge, attitude and perceived adoption of modern wheat production technologies among the demonstrating as well as neighboring farmers.

\section{Methodology}

Varietal interaction with different levels of soil moisture stress was assessed against a number of agronomic and physiological parameters. The trial's main plots were used for four irrigation regimes i.e. no irrigation, 1 irrigation at crown root formation stage (20 days after sowing), 2 irrigations (one at crown root formation and $2^{\text {nd }}$ at booting stage) and 3 irrigations ( 1 at crown root formation, 1 at booting and the $3^{\text {rd }}$ at grain-filling stage) were applied to 6 selected wheat varieties, and 1 allotted to each Sub-Plot $\left(5 \mathrm{~m}^{2}\right.$ size each) against the concerned main plots. The wheat varieties included BARI Gom21, BARI Gom23, BARI Gom24, BARI Gom25, BARI Gom26 and BARI Gom27. The trial was replicated in 4 farmer's plots. Data on yield and selected yield contributing factors were collected all over the 
crop growing period. Weather-related data were also gathered from different sources. A split-plot design was used in setting adaptive trials for assessing the interaction of 6 modern wheat varieties against the different level of soil moisture stress as follows:

\subsection{Design: Split-Plot}

\subsubsection{Factor A: Irrigation (I), Main Plot}

$\mathrm{I}_{\mathrm{o}} \quad=$ No irrigation (rainfed), full moisture stress

$\mathrm{I}_{1}=1$ irrigation at crown root initiation i.e. 20 days after sowing, high moisture stress

$\mathrm{I}_{2}=2$ irrigations, 1 st at crown root stage and 2 nd at booting stage (55 days after sowing), low moisture stress

$\mathrm{I}_{3}=3$ irrigations, $1^{\text {st }}$ at crown root stage, $2^{\text {nd }}$ at booting stage and $3^{\text {rd }}$ irrigation at grain filling stage ( 75 days after sowing), no moisture stress

\subsubsection{Factor B: Varieties (V), Sub-plots \\ $\mathrm{V} 1=$ BARIGom 21 (Shatabdi) \\ V2 = BARIGom 23 (Bijoy) \\ V3 = BARIGom 24 (Prodip) \\ V4 = BARIGom 25 \\ V5 = BARIGom 26 \\ V6 = BARIGom 27}

Size of each Sub-plot was $5 \mathrm{~m}^{2}$

This trial was replicated in 4 farmers' fields, 2 in Saidpur and 2 in Jaldhaka Upazila of Nilphamari district. Al the trials were established from 5-9 December 2012 after harvesting T. Aman by the farmers. Inputs such as fertilizers, dollochune, and boron were used as per the recommendation of BARI.

\subsection{Crop-related Data to Be Taken:}

i Germination $\%$ ii Number of tillers $/ \mathrm{m}^{2}$

iii Number of tillers/plant

iv Number of effective tillers/plant

v Total leaf area $/ \mathrm{m}^{2}$ ofland

vi Leaf Area Index

vii Average plant height after 30, 45, 60 days of sowing and at harvest time

viii Number of days of first heading after sowing \& No. of days of $50 \%$ heading after sowing

ix Number of days of $90 \%$ maturity after sowing

$\mathrm{x}$ Number of days from sowing to harvesting days

xi Number of Spikes $/ \mathrm{m}^{2}$

xii Length of each spike

xiii Number of grains/Spike

xiv Number of grains/main Spike

xv Grain yield/clump

xvi 1000grain weight

xvii Number of unfilled grain/spike

xviii The weight of Straw/ha

xix Harvest Index

\subsection{Weather-related Data to Be Taken}

Minimum, maximum and average temperature, humidity, daily sunshine hours, number of foggy days, rainfall etc. from $1^{\text {st }}$ January to $15^{\text {th }}$ February

\section{Study Findings}

\subsection{Varietal Interaction with Drought Stress Yield}

Mean yields of all the varieties obtained from adaptive trials against ' 0 ', 1, 2 and 3 irrigations are mentioned in Table 1.

Table 1. Mean Yields (Ton/ha) of 6 selected varieties against '0', 1, 2 and 3irrigations.

\begin{tabular}{|c|c|c|c|c|c|c|c|}
\hline \multirow{2}{*}{ Irrigation } & \multicolumn{7}{|l|}{ Varieties } \\
\hline & BARIGom21 & BARIGom23 & BARIGom24 & BARIGom 25 & BARIGom26 & BARIGom27 & AllVarieties \\
\hline OIrrigation & 4.05 & 3.95 & 3.95 & 3.97 & 3.99 & 3.89 & 3.97 \\
\hline 1irrigation & 4.24 & 4.07 & 4.61 & 4.39 & 4.25 & 4.38 & 4.32 \\
\hline 2irrigation & 4.11 & 4.39 & 4.59 & 4.47 & 4.45 & 4.43 & 4.41 \\
\hline 3irrigation & 4.68 & 4.56 & 4.94 & 4.69 & 4.73 & 4.57 & 4.70 \\
\hline LSD & 0.26 & 0.82 & 0.19 & 0.56 & 0.47 & 1.18 & \\
\hline CV (\%) & 6.64 & 9.40 & 10.02 & 7.77 & 7.62 & 12.20 & \\
\hline
\end{tabular}

Data in Table 1 revealed that BARI Gom 21 gives similar yield against 0,1 and 2 irrigations but these yields are significantly lower compared to yield obtained in case 3 irrigations. Here, third irrigation contributed to making a significant difference. Level of irrigation did not make any significant difference in yield in case of BARI Gom23 though yield obtained in'0' irrigation found as lowest. The yield of BARI Gom24 (3.95 ton/ha) was found significantly lowest in ' 0 ' irrigation compared to 1,2 and 3 irrigations. This variety yielded highest (4.94 ton/ha) against 3 irrigations. BARI Gom 24 gave statistically similar yields in case of 0,1 and 2 irrigations though it yielded much less in case of ' 0 ' irrigation. The variety yielded significantly higher (4.94 ton/ha) against 3 irrigations compared to 2, 1 and 0 irrigation. BARI Gom25 gave statistically similar yield though yielded lowest (3.97 tons/ha) in ' 0 ' irrigation. The variety obtained significantly highest yield in 3 irrigation compared to the yield of ' 0 ' irrigation (3.97 ton/ha) but similar yield with 2 and 1 irrigation. Significantly lowest yield (3.99 ton/ha) of the variety BARI Gom26 was observed in case ' 0 ' irrigation (3.99 ton/ha) compared to the yield obtained in 3 irrigations (4.73 ton/ha). Yield observed in 1 irrigation (4.25 ton/ha) was also significantly lowest compared to the yield of 3 irrigation, but yielded no significant difference between 2 and 3 irrigation. Yields obtained in all the three irrigation regimes for BARI Gom27 were found statistically similar though it yielded lowest (3.89 ton/ha) in case of ' 0 ' irrigation and highest ( 4.57 ton/ha) in 3 irrigations. 


\subsection{Major Findings}

i Yields obtained were found lower in ' 0 ' irrigation, mostly significantly lower compared 3 irrigation in all the 6 varieties.

ii Yields obtained in 3 irrigations were found highest in all the six varieties.

iii The yield difference between ' 0 ' and $1,1 \& 2$ and $2 \& 3$ did not reveal significant difference except BARI Gom24 where yields of all the irrigation treatments differed significantly. In most cases, significant differences were observed between ' 0 ' and 3 irrigations.

iv Considering all varieties and number of irrigation, BARI Gom24 yielded highest in 3 irrigations while BARI Gom27 obtained the lowest yield in ' 0 ' irrigation.

v BARI Gom21 performed comparatively better in ' 0 ' irrigation.

vi The yield obtained in ' 0 ' irrigation (average of all varieties $=3.97$ tons $/$ ha) can be considered satisfactory compared to the yield potentialities of these varieties which range mostly from (3.5 to 5.0 tons/ha), national average yield (2.78 ton/ha) and taking account of irrigation costs.

\subsection{Varietal Interaction with Drought Stress: Yield Contributing Factors}

High High temperature $\left(>30^{\circ} \mathrm{C}\right)$ at the time of grain filling is one of the major constraints in increasing productivity of wheat in tropical and sub-tropical countries [15]. A reduction of $28.9 \%$ grain yields of wheat was reported to in response of heat stress and heat stress caused a reduction of 8.5, 7.6, 5.6 percent for canopy temperature depression in 1000-grain weight, grain filling period and membrane injury (grain filling stage) respectively [16]. With increase in stress intensity, a progressive and significant decrease was observed in yield and yield attributing traits in all wheat varieties [17]. The yield of a crop is the combined and integrated effect of some major yield contributing factors. How drought and irrigated situation affects to these yield contributing factors were assessed and mentioned in Table 2 to Table 12. Oneway Analysis of Variance (ANOVA) and Duncan test for multiple means comparison was computed to see whether there exists significant difference among the mean values as well as to see the similarities and differences between the means.

Significantly highest number of Tillers $/ \mathrm{m}^{2}$ was observed in case of the variety BARI Gom 26 and BARI Gom 27 in 3 irrigations compared to ' 0 ' irrigation. Other varieties yielded no significant difference (Table 2). No. of effective Tillers (Table 3) was found significantly highest in case of 3 irrigations in most of the varieties compared to ' 0 ' irrigation. Regarding Leaf Area Index (LAI), it is significantly highest in case of 3 irrigation for varieties BARI Gom25, BARI Gom 26 and BARI Gom27 (Table 4). The average height of plant at 60 days after sowing found highest in 3 irrigation compared to ' 0 ' irrigation (Table 5).

Table 2. Average No of Tillers $/ \mathrm{m}^{2}$.

\begin{tabular}{|c|c|c|c|c|c|c|}
\hline \multirow{2}{*}{ Irrigation } & \multicolumn{6}{|l|}{ Varieties } \\
\hline & BARIGom21 & BARIGom23 & BARIGom24 & BARIGom25 & BARIGom26 & BARIGom27 \\
\hline 0Irrigation & $521.67 b$ & $434.44 b$ & $454.44 b$ & 489.67 & $502.78 b$ & $523.78 b$ \\
\hline 1 irrigation & 765.78ab & $756.00 \mathrm{ab}$ & $721.00 \mathrm{ab}$ & 701.44 & $681.89 \mathrm{ab}$ & $946.33 \mathrm{a}$ \\
\hline 2irrigation & $697.72 \mathrm{ab}$ & $807.56 \mathrm{ab}$ & $775.77 \mathrm{ab}$ & 823.44 & $886.22 \mathrm{a}$ & $939.67 \mathrm{a}$ \\
\hline 3irrigation & $881.00 \mathrm{a}$ & $843.22 \mathrm{a}$ & $884.22 \mathrm{a}$ & 831.11 & $891.89 a$ & $940.22 \mathrm{a}$ \\
\hline $\mathrm{F}$ & 2.730 & 2.673 & 3.367 & 1.451 & $3.791 *$ & $7.645^{* *}$ \\
\hline
\end{tabular}

Table 3. Number of Effective Tillers/Plant.

\begin{tabular}{lllllll}
\hline \multirow{2}{*}{ Irrigation } & Varieties & & & & \\
& BARIGom21 & BARIGom23 & BARIGom24 & BARIGom25 & BARIGom26 & BARIGom27 \\
\hline 0Irrigation & $4.10 \mathrm{~b}$ & $5.20 \mathrm{~b}$ & $3.77 \mathrm{~b}$ & $4.27 \mathrm{~b}$ & 4.90 & 4.63 \\
1irrigation & $4.70 \mathrm{ab}$ & $6.00 \mathrm{~b}$ & $4.87 \mathrm{a}$ & $4.90 \mathrm{ab}$ & 5.33 & 5.37 \\
2irrigation & $5.20 \mathrm{a}$ & $6.00 \mathrm{~b}$ & $5.13 \mathrm{a}$ & $5.20 \mathrm{a}$ & 5.33 & 5.27 \\
3irrigation & $5.30 \mathrm{a}$ & $7.37 \mathrm{a}$ & $5.87 \mathrm{a}$ & $5.30 \mathrm{a}$ & 5.83 & 5.27 \\
F & $10.37^{* *}$ & $3.96^{*}$ & $8.026^{* *}$ & $4.457^{*}$ & 1.172 & 0.559 \\
\hline
\end{tabular}

Table 4. Leaf Area index (LAI).

\begin{tabular}{lllllll}
\hline \multirow{2}{*}{ Irrigation } & Varieties & & & & & \\
\cline { 2 - 7 } & BARIGom21 & BARIGom23 & BARIGom24 & BARIGom25 & BARIGom26 & BARIGom27 \\
\hline 0Irrigation & 2.47 & 2.69 & $2.64 \mathrm{~b}$ & $2.91 \mathrm{~b}$ & 3.29 & $2.56 \mathrm{~b}$ \\
1irrigation & 2.51 & 3.09 & $3.35 \mathrm{~b}$ & $2.87 \mathrm{~b}$ & 3.64 & $3.27 \mathrm{a}$ \\
2irrigation & 2.60 & 3.14 & $3.21 \mathrm{a}$ & $3.72 \mathrm{a}$ & 3.98 & $3.70 \mathrm{a}$ \\
3irrigation & 3.18 & 3.29 & $3.04 \mathrm{a}$ & $2.70 \mathrm{~b}$ & 3.90 & $3.62 \mathrm{a}$ \\
F & 0.853 & 1.118 & 3.457 & $5.273^{*}$ & 1.377 & 3.320 \\
\hline
\end{tabular}


Table 5. Average Plant Height at 60 days of Sowing.

\begin{tabular}{lllllll}
\hline \multirow{2}{*}{ Irrigation } & Varieties & & & & & BARIGom26 \\
\cline { 2 - 7 } & BARIGom21 & BARIGom23 & BARIGom24 & BARIGom25 & BARIGom27 \\
\hline 0Irrigation & $66.60 \mathrm{~b}$ & $65.40 \mathrm{~b}$ & $61.53 \mathrm{~b}$ & 69.87 & $66.00 \mathrm{~b}$ & $65.47 \mathrm{~b}$ \\
1irrigation & $71.87 \mathrm{~b}$ & $71.77 \mathrm{ab}$ & $70.83 \mathrm{ab}$ & 71.83 & $68.07 \mathrm{ab}$ & $68.57 \mathrm{ab}$ \\
2irrigation & $75.00 \mathrm{ab}$ & $80.40 \mathrm{ab}$ & $77.93 \mathrm{ab}$ & 79.90 & $77.50 \mathrm{ab}$ & $78.60 \mathrm{ab}$ \\
3irrigation & $91.43 \mathrm{a}$ & $90.50 \mathrm{a}$ & $87.40 \mathrm{a}$ & 80.00 & $81.73 \mathrm{a}$ & $83.33 \mathrm{a}$ \\
F3 & $3.508^{*}$ & $3.484^{*}$ & 3.189 & 1.102 & 3.112 & $3.634^{*}$ \\
\hline
\end{tabular}

Table 6. Number of Days required for $50 \%$ Heading from sowing.

\begin{tabular}{lllllll}
\hline \multirow{2}{*}{ Irrigation } & Varieties & & & & \\
\cline { 2 - 7 } & BARIGom21 & BARIGom23 & BARIGom24 & BARIGom25 & BARIGom26 & BARIGom27 \\
\hline OIrrigation & 73.00 & 73.33 & 72.67 & $73.00 \mathrm{a}$ & $74.67 \mathrm{a}$ & $72.67 \mathrm{a}$ \\
1irrigation & 73.67 & 73.00 & 72.00 & $73.12 \mathrm{a}$ & $73.00 \mathrm{a}$ & $72.07 \mathrm{a}$ \\
2irrigation & 73.33 & 73.00 & 72.00 & $72.64 \mathrm{a}$ & $74.00 \mathrm{a}$ & $71.88 \mathrm{a}$ \\
3irrigation & 71.33 & 73.00 & 72.67 & $67.00 \mathrm{~b}$ & $68.00 \mathrm{~b}$ & $67.67 \mathrm{~b}$ \\
F & 1.289 & 0.032 & 0.267 & $7.20^{* *}$ & $7.651^{* *}$ & $8.43^{* *}$ \\
\hline
\end{tabular}

Table 7. Number of days required for $90 \%$ maturity from seed sowing.

\begin{tabular}{lllllll}
\hline \multirow{2}{*}{ Irrigation } & Varieties & & & & & BARIGom26 \\
\cline { 2 - 7 } & BARIGom21 & BARIGom23 & BARIGom24 & BARIGom25 & BARIGom27 \\
\hline OIrrigation & 108.67 & 108.00 & 108.33 & 106.67 & 105.00 & 108.00 \\
1irrigation & 110.00 & 109.00 & 111.00 & 108.33 & 109.33 & 111.33 \\
2irrigation & 110.00 & 110.33 & 111.00 & 108.67 & 108.67 & 111.20 \\
3irrigation & 111.33 & 110.67 & 110.67 & 110.33 & 109.33 & 110.80 \\
F & 0.281 & 0.162 & 0.360 & 0.196 & 0.313 & 0.512 \\
\hline
\end{tabular}

Table 8. Mean length of Spike (cm).

\begin{tabular}{lllllll}
\hline \multirow{2}{*}{ Irrigation } & Varieties & & & & & BARIGom26 \\
\cline { 2 - 7 } & BARIGom21 & BARIGom23 & BARIGom24 & BARIGom25 & BARIGom27 \\
\hline OIrrigation & 13.00 & 11.67 & 13.00 & 12.33 & 11.33 & 12.67 \\
1irrigation & 13.33 & 11.67 & 13.33 & 13.33 & 11.00 & 12.67 \\
2irrigation & 12.67 & 12.00 & 13.33 & 13.33 & 11.00 & 13.67 \\
3irrigation & 13.33 & 12.33 & 13.67 & 13.00 & 11.67 & 13.67 \\
F & 0.064 & 0.122 & 0.074 & 0.333 & 0.310 & 0.197 \\
\hline
\end{tabular}

Table 9. Average Number of Grains/Spike.

\begin{tabular}{lllllll}
\hline \multirow{2}{*}{ Irrigation } & Varieties & & & & \\
\cline { 2 - 7 } & BARIGom21 & BARIGom23 & BARIGom24 & BARIGom25 & BARIGom26 & BARIGom27 \\
\hline OIrrigation & 45.67 & 45.00 & 45.67 & $47.00 \mathrm{a}$ & 45.67 & 48.33 \\
1irrigation & 45.00 & 48.00 & 50.33 & $36.33 \mathrm{~b}$ & 48.67 & 44.33 \\
2irrigation & 46.67 & 45.33 & 45.00 & $40.67 \mathrm{ab}$ & 49.67 & 48.67 \\
3irrigation & 49.33 & 46.67 & 48.00 & $47.00 \mathrm{a}$ & 55.00 & 47.00 \\
F & 0.305 & 0.139 & 0.615 & $3.903^{*}$ & 0.367 & 0.443 \\
\hline
\end{tabular}

Table 10. Average Weight (g) of 1000 Grains.

\begin{tabular}{lllllll}
\hline \multirow{2}{*}{ Irrigation } & Varieties & & & & & \\
\cline { 2 - 7 } & BARIGom21 & BARIGom23 & BARIGom24 & BARIGom25 & BARIGom26 & BARIGom27 \\
\hline OIrrigation & 46.33 & 48.00 & $56 \ldots .00$ & 51.67 & 49.67 & $46.67 \mathrm{ab}$ \\
1irrigation & 54.00 & 49.04 & 52.67 & 49.67 & 45.33 & $45.00 \mathrm{ab}$ \\
2irrigation & 52.07 & 46.33 & 52.67 & 61.00 & 43.67 & $40.33 \mathrm{~b}$ \\
3irrigation & 52.33 & 48.67 & 53.00 & 50.67 & 48.33 & $51.33 \mathrm{a}$ \\
F & 2.069 & 0.387 & 2.301 & 2.526 & 1.629 & $4.268^{*}$ \\
\hline
\end{tabular}

Table 11. Number of Unfilled Grains/Spike.

\begin{tabular}{lllllll}
\hline \multirow{2}{*}{ Irrigation } & Varieties & & & & & \\
\cline { 2 - 7 } & BARIGom21 & BARIGom23 & BARIGom24 & BARIGom25 & BARIGom26 & BARIGom27 \\
\hline OIrrigation & 12.67 & 8.33 & 10.67 & 8.67 & $11.67 \mathrm{a}$ & 9.00 \\
1irrigation & 9.33 & 9.67 & 8.00 & 8.00 & $11.33 \mathrm{a}$ & 8.00 \\
2irrigation & 9.33 & 10.00 & 8.33 & 8.67 & $7.67 \mathrm{~b}$ & 10 \\
3irrigation & 8.33 & 8.67 & 9.00 & 8.67 & $9.33 \mathrm{~b}$ & 8.33 \\
F & $8.062 * *$ & 1.916 & 1.949 & 0.667 & $12.533 * *$ & 2.154 \\
\hline
\end{tabular}


Table 12. Harvest Indices (\%).

\begin{tabular}{lllllll}
\hline \multirow{2}{*}{ Irrigation } & Varieties & & & \\
\cline { 2 - 6 } & BARIGom21 & BARIGom23 & BARIGom24 & BARIGom25 & BARIGom26 & BARIGom27 \\
\hline 0Irrigation & $33.54 \mathrm{~b}$ & 35.55 & $37.28 \mathrm{~b}$ & 35.16 & $37.73 \mathrm{~b}$ \\
1irrigation & $37.33 \mathrm{a}$ & 38.15 & $41.28 \mathrm{a}$ & 38.78 & $40.44 \mathrm{ab}$ \\
2irrigation & $36.75 \mathrm{a}$ & 37.26 & $40.70 \mathrm{ab}$ & 38.92 & 39.03 \\
3irrigation & $41.14 \mathrm{a}$ & 40.79 & $42.66 \mathrm{a}$ & 40.69 & 49 & $44.01 \mathrm{a}$ \\
F & 3.280 & 0.600 & $4.100^{*}$ & 2.606 & $4.229 *$ \\
\hline
\end{tabular}

Regarding days to $50 \%$ heading, varieties received no irrigation taken significantly more days to $50 \%$ heading compared to 3 irrigations in BARI Gom 25, BARI Gom 26 and BARI Gom 27. Regarding a number of days to 90\%maturity (Table 7) no significant difference among the varieties and irrigation was observed. Similar is the case of Spike length (Table 8). Regarding grain number/spike (Table 9) in case of BARI Gom25, it is significantly highest in ' 0 ' and 3 irrigation compared to 1 and 2 irrigation. Regarding the weight of 1000 grains (Table 10), it is only in case of BARI Gom 27 the weight is significantly highest in 3 irrigation. A number of unfilled grains (Table 11) observed highest in almost all the varieties in case of ' 0 ' irrigation. It is significantly highest in case of BARI Gom 21 against ' 0 ' irrigation compared to 1, 2 and 3 irrigation. Harvest indices (Table 12) were observed significantly higher in case of 3 irrigations compared to ' 0 ' irrigation in varieties BARI Gom24 and BARI Gom26.

\subsection{Major Finding}

Most of the yield contributing parameters were found significantly affected by ' 0 ' irrigation and positively enhanced by the higher number of irrigations.

\subsection{Relationship Between Yield and Yield Contributing Characters}

Correlation analysis showing the relationship of various yield contributing characters with the yield of all the varieties is shown in Table 13. Analysis based on drought trial data showed that yield of tested 6 wheat varieties significantly (positive) correlated with number of tillers $/ \mathrm{m} 2$, no. of tillers/plant, number of effective tillers/plant, average plant height after 60 days of sowing and at harvest, grain number/main spike, weight of straw and Harvest Indices. The significant negative relationship was observed with a number of first heading days from sowing, 50\% heading days and number of unfilled grains/spike. This means that varieties headed early and have a number of unfilled grains yielded low. More or less similar trend of relationship also observed in using Cold Stress Trial data. Here, number of tillers $/ \mathrm{m} 2$, number of tillers/plant and number of effective tillers/plant did not show a significant relationship with yield.

Table 13. Correlation analyses showing the relationship of wheat yield and Yield contributing factors.

\begin{tabular}{lll}
\hline Sl. & Yield contributing factors & 'r' based on drought trial \\
\hline 1 & No. of tillers $/ \mathrm{m}^{2}$ & $0.435^{* *}$ \\
2 & No. of tillers/plant & $0.461^{* *}$ \\
3 & No. of effective tillers/plant & $0.440^{* *}$ \\
4 & Leaf Area Index & 0.308 \\
\hline
\end{tabular}

\begin{tabular}{lll}
\hline Sl. & Yield contributing factors & ' $\mathbf{r}$ ' based on drought trial \\
\hline 5 & Average plant height in 60DAS & $0.478^{* *}$ \\
6 & Average plant height at harvest & $0.232^{*}$ \\
7 & First heading days (DAS) & $-0.272^{*}$ \\
8 & $50 \%$ headings (DAS) & $-0.318^{* *}$ \\
9 & $90 \%$ maturity (DAS) & 0.129 \\
10 & Harvesting days (DAS) & \\
10 & Av. No. of Spikes/m ${ }^{2}$ & 0.158 \\
11 & Av. Length of each spike & 0.095 \\
12 & Grain No./Spike & 0.210 \\
13 & Grain No .of main Spike & $0.252^{*}$ \\
6 & Grain yield/clump & -0.013 \\
14 & The weight of 1000 grainweight & -0.063 \\
15 & No. of unfilled grain/spike & $-.266^{*}$ \\
16 & The weight of Straw/ha & $0.48^{* *}$ \\
17 & Harvest Index & $0.500^{* *}$ \\
\hline
\end{tabular}

Rather, Leaf Area Index (LAI), the average length of the spike, grain yield/clump, weight of straw and Harvest Index showed a significant positive relationship with yield. On the other hand, first heading days, 50\% heading days, $90 \%$ maturity days, harvesting days and number of unfilled grains/spike showed a significant negative relationship with yield.

\subsection{Field Days}

Three field days were organized in 3 project sites where 250 farmers participated. DAE officials, officials from CSISA, local journalists also joined together with the participating farmers in sharing experiences, visiting the Trial and Demonstration plots and participating in crop cuttings. All the Field Days were full of joys, the pleasure of achieving great successes by the farmers who sent clear messages to those who have not yet started improved wheat cultivation.

\subsection{Validation Workshop}

Major findings of the study were finally shared with the farmers who raised Trials and Demonstration plots in a Validation Workshop organized last week of April/2013.

\section{Study Outcomes}

i Adaptive Trial findings showed that although irrigation increases yield of wheat but yields obtained in nonirrigated rainfed condition were also found satisfactory in all the six varieties, which are within the potential yields of the respective varieties and also higher than the national average yield.

ii Large-scale demonstration of modern wheat varieties and technologies generated huge interest and awareness among the marginal and small farmers in the project area. 


\section{Recommendations}

The satisfactory yield of wheat can be obtained under rainfed condition using residual soil moisture. What is needed is the access of the small and marginal farmers to seeds of recently released high yielding varieties and production technologies. Availability of quality seeds and training on improved cultivation practices is very essential for these disadvantaged farmers. Based on study findings following recommendations are forwarded:

i Farmer-to-Farmer exchange of seed materials in the project area needs to be strengthened. RIB should concentrate its emphasis through Community Seed Banks now in operation in some parts of Nilphamari district.

ii DAE should also help these farmers in obtaining seed materials and organizing training programmes. Farmers should also be trained and encouraged to produce and store quality wheat seeds.

\section{Acknowledgements}

This research program was implemented with the support of Programme Support The unit, Agricultural Sector Programme Support-II (ASPS-II), Planning Commission Bangladesh (PSU-PC), People's Republic of Bangladesh. We are grateful to Dr. Korban Ali for his valuable contribution he has made.

\section{References}

[1] Amandeep, K., Sohu, V. S. and Mavi, G. S. Genotypic variation for physiological traits associated with heat tolerance in bread wheat (Triticumaestivum L.). Crop. Improvement, 34 (2): 117-123. 2007.

[2] J. A. Syeda (2017). Impact of Climate Change on Wheat Production in Dinajpur Region of Bangladesh: an Econometric Analysis. J. Environ. Sci. \& Natural Resources, 10 (2): 157-162, 2017.

[3] Mikhail A Semenov. Climate change impact and adaptation for wheat protein. https://www.researchgate.net/publication/328955939_Climate change_impact_and_adaptation_for_wheat_protein ${ }^{-}$on Nov 22,2018 .

[4] Godfray, H., Charles J., et al. (2010) Food Security: The Challenge of Feeding 9 Billion People. Science, 327, 812-818.
[5] Wheeler, T. and von Braun, J. (2013) Climate Change Impacts on Global Food Security. Science, 341, 508-513. http://dx.doi.org/10.1126/science.1239402

[6] M, Rosegrant, X, Cai, S, Cline, and N, Nakagawa (2002) The Role of Rainfed Agriculture in the Future of Global Food Production. International Food Policy Research Institute 2033 K Street, N. W. Washington, D. C. 20006 U.S.A.

[7] Rosegrant MW, M, Agcaoili. (2010) Global food demand, supply, and price prospects to 2010. Washington, DC:. [Google Scholar].

[8] https://www.ipcc.ch/site/assets/uploads/2018/03/ar4_wg2_full _report.pdf

[9] CIMMYT and ICARDA. 2011. WHEAT—global alliance for improving food security and the livelihoods of the resourcespoor in the developing world. Proposal submitted by CIMMYT and ICARDA to the CGIAR consortium board, in collaboration with Biodiversity, ICRISAT, IFPRI, ILRI, IRRI, IWMI, 86 NARS Institute, 13 Regional and International Organizations, 71 Universities and Advance Research Institutes, 15 Private Sector Organizations, 14 NGOs and Farmers Cooperatives and 20 Host Countries, 197.

[10] http://www.oecd.org/berlin/43042301.pdf

[11] Hossain A, Teixeira da Silva JA. 2013. Wheat production in Bangladesh: its future in the light of global warming. AoB PLANTS 5: pls042; doi: 10.1093/aobpla/pls042

[12] John, W. Schmid (1983). Drought resistance and wheat breeding, Agricultural Water Management, Volume 7, Issues 1-3, September 1983, Pages 181-194.

[13] Drought-tolerant wheat varieties gain popularity in Barind. http://www.theindependentbd.com/arcprint/details/81328/2017-02-18

[14] BARI (Bangladesh Agricultural Research Institute). 2012b. Year of release and average yield of Bangladesh wheat varieties developed since 1974.

[15] Rane, J. and Nagarajan, S. 2004. High temperature index-for field evaluation of heat tolerance in wheat varieties. Agricultural Systems, 79 (2): 243-255.

[16] Amandeep, K., Sohu, V. S. and Mavi, G. S. 2007. Genotypic variation for physiological traits associated with heat tolerance in bread wheat (Triticum aestivum L.). Crop. Improvement, 34 (2): 117-123.

[17] Singh, J. P., Shambhoo P., Singh K. N., and Randhir S. 2007. Screening of heat tolerant wheat varieties by membrane thermostability index in relation to yield and yield attributing traits. Int. J. Plant Sci. Muzzaffarmagar, 2 (2): 159-165. 